Институт за словеначку књижевност и науку о књижевности

Научно-истраживачки центар Словеначке академије наука и уметности, Љубљана

\begin{abstract}
Апстракт: Егземпларност романа Михе Мацинија, Полоне Главан и Дина Баука хвата се укоштац са словеначким дискурсом „организоване невиности“ (Јаглушич) и унутар граница естетске репрезентације покушава да пробуди наклоност према људима које је словеначка власт избрисала из регистра грађана са сталним пребивалиштем. Поменути романи метонимијски представљају популацију тзв. избрисаних, којима је словеначка биополитика након проглашења независности насилно одузела права и редуковала их на „голи живот“ (Агамбен), фокусирајући се на хуманизовану жртву брисања, при чему се разоткрива однос тзв. обичних људи према овом масовном кршењу људских права.

Кључне речи: биополитика, етнонационализам, траума, порицање кривице, словеначки роман, егземпларност
\end{abstract}

\title{
Генеалогија избрисаних
}

Последице административног брисања из регистра грађана са сталним пребивалиштем у Словенији, које се догодило 26. фебруара 1992. године, у независној словеначкој држави погодиле су око 25.000 становника, који у бившој Југославији нису имали словеначко републичко држављанство већ или југословенско или држављанство једне од других република СФРЈ. ${ }^{2}$ Тим поступком словеначке власти - тек неколико месеци након проглашења државне независности (25. јуна 1991) и тзв. Десетодневног рата за независност - без претходних упозорења и објављених и издатих одлука одузеле су појединцима сва грађанска, социјална и политичка права. Избрисани грађани нове државе изгубили су здравствено и пензионо осигурање и дозволу за рад, поставши апатриди. ${ }^{3}$ По закону

1 Чланак је настао у оквиру истраживачких програма Р6-0239 и J6-8259, које је Јавна агенција за истраживачку делатност Републике Словеније суфинансирала из државног буџета.

2 Избрисани су етнички у већини случајева припадници других југословенских народа, односно, потомци родитеља од којих је бар један тзв. несловенац. У погледу хронологије избрисаних у наставку се ослањам на: Dedić, Jalušič и др. 2003; Pistotnik 2007; Breznik i Močnik 2011; Zdravković 2014.

3 Агамбен (2006: 109-117) наводи да сличну „масовну денатурализацију и денацио- 
о држављанству и закону о странцима, усвојеним 1991. године, словеначко држављанство није било додељено свим грађанима који су имали стално боравиште, већ само оним који су у СФРЈ већ имали словеначко држављанство. Грађани Словеније с несловеначким републичким или заједничким југословенским држављанством морали су за словеначко држављанство поднети молбу у року од шест месеци од усвајања Закона о држављанству. Око 172.000 подносилаца молбе добило је словеначко држављанство, међутим, избрисани га нису добили, будући да им је молба била одбијена или је пак уопште нису ни поднели, било због необавештености и непажње било због одбацивања статуса словеначког држављана. Кључно је да им није било објашњено да ће без словеначког држављанства изгубити и право на стално пребивалиште које су добили и да ће тако постати илегални странци. Завела их је притом и Основна уставна повеља о самосталности и независности Словеније, усвојена на дан осамостаљења, која је гарантовала „очување људских права и основних слобода свим појединцима на територији Републике Словеније независно од њихове националне припадности, без икакве дискриминације“ (Ustava 2005: 7-8).

Искључивањем из словеначког правног система избрисани су искључени из свих механизама социјалне заштите грађана и тржишта рада. Будући да нису могли ни изнова добити страни пасош ни испунити услове за поновно добијање сталног пребивалишта били су присиљени да се као илегални странци издржавају радом на црно, ослањајући се на помоћ ближњих и филантропа, а неки су нашли излаз у криминалу. Онај кога би ухватила полиција, након привременог боравка у домовима за странце, чекао би могући прогон из Словеније, што је укључивало и могућност депортације на ратом захваћене територије (упореди: Zorn, 2003: 115-123). Избрисани су радом на црно постали извор обесправљене и јефтине радне снаге (упореди: Gregorčič 2007: 88; Breznik i Močnik 2011: 52-58).

До брисања, које су пресуде словеначког Уставног суда (1999, 2003) и Европског суда за људска права (2012) препознале као масовно кршење људских права, дошло је услед актуалних политичких и историјских разлога који су сви одреда повезани с етнонационалистичком концепцијом државности.

Од седамдесетих година XX века, када је у развијенију Словенију масовно почело досељавање радника из јужних југословенских република (в.: Dolenc 2007), који су и иначе зарад свог класног положаја наилазили на потешкоће током интеграције у нову средину, међу Словенцима, ненавикнутим на урбану мултикултуралност и преосетљивим на (не)правилно коришћење словеначког језика,

нализацију својих грађана“ у националистичком XX веку познају и многе друге европске државе, а искључивање недржављана из механизама социјалне државе и заштите људских права је глобална појава (на пример, недавна мигрантска криза). 
почеле су да се шире предрасуде према тзв. јужњацима (Mežnarić 1986), које су биле повезане с убеђењем да они угрожавају њихова радна места, језик и идентитет. ${ }^{4}$

Након смрти ауторитативног и харизматичног вође Јосипа Броза Тита, Социјалистичка Федеративна Република Југославија запала је у дубоку дужничку, економску и идеолошку кризу током које су се распламтела међуетничка трвења, тако да су тзв. нерешена национална питања, присутна од почетка осамдесетих година XX века до распада федерације у рату, постала приоритет политичких програма, како појединачних републичких фракција Комунистичке партије тако и опозиције културних делатника, који су се у већини случајева, иначе, заузимали за страначки плурализам, ослањајући се притом на западњачки модел. Поменуте југословенске појаве биле су симптом победничке економске превласти капиталистичког светског система, који је имао свој центар на Западу, над комунистичким тоталитаризмом, с центром на совјетском Истоку. У дужничкој кризи распаљени југословенски национализми били су део светског модела у којем се препознавање социјалне неједнакости имунизирало преусмеравањем пажње на политику културних идентитета; након јењавања студентско-радничког покрета шездесетих година, овај модел се глобализовао. Југословенске масе, под притиском западњачких зајмодаваца изложене оштрим мерама штедње и немаштини, биле су фасциниране сликом конзумеристичког обиља капитализма. Интелектуалци свих генерација који су били укључени у друштвене покрете новијег датума усвојили су либералистички дискурс о људским правима, који је, у већини случајева, био преплетен, с једне стране, с представом о вишестраначком плурализму, који је фигурирао као противотров за недемократску једнопартијску хегемонију и, с друге стране, с представом о цивилизованом моделу правне и социјалне државе западноевропског типа, која гарантује ограничавање самовоље власти и очување друштвене једнакости познате у социјализму.

У Словенији, најразвијенијој југословенској републици, осамдесетих година јављају се тежње за политичким плурализмом, демократизацијом и увођењем људских права. Оне су често хетерогене и идеолошки неспојиве: у тзв. опозицији културних делатника окупљених око Нове ревије, ове тенденције у већини случајева биле су, под утицајем пробуђеног национализма, повезане са захтевом за националном самосталношћу, вишестраначким системом и грађењем снажнијих веза са Средњом и Западном Европом; од нових друштвених покрета преузимале су се алтернативне концепције демократије „одоздо“, нарочито идеја самоорганизованог, аутоном-

4 Чак 57,5 одсто анкетираних Словенаца током истраживања словеначког јавног мњења 1990. године и даље је мислило да досељавање радника из југословенских република угрожава Словенце (Medvešek 2007: 195). 
ног и плуралног цивилног друштва које би превазишло државу која му стоји насупрот. Тежња за самосталном словеначком националном државом као оквиром који ће гарантовати остваривање људских права и политичког плурализма, ојачала је при крају осамдесетих година, нарочито као реакција на агресивну политику тадашње српске комунистичке партије, која је под ауторитарним вођством Слободана Милошевића изводила кадровске чистке у матичној републици, изрицала дисциплинске казне косовским Албанцима, да би потом на масовним митинзима тзв. антибирократске револуције изразила намеру да својим популистичким моделом, рачунајући на помоћ војне силе, превлада у целој Југославији. То је у Словенији, у којој је војска интервенисала у младо цивилно друштво током тзв. Поступка против четворице 1988. године, појачало утисак угрожености од JНА, а превласт већинског језика федерације над словеначким схваћена је као темељ националне идентификације. У оваквим условима су у Словенији већ ојачале предрасуде према другим југословенским народима. А када је Словенију, у којој су већ били изведени слободни и демократски избори, као и плебисцит о проглашењу независности, Југословенска народна армија у јуну 1991. године, свега дан након проглашења, уистину напала, ове предрасуде су прерасле у ксенофобију и мржњу. Улогу Немаца и немачког језика из словеначког народноослободилачког имагинарија XIX века, који се формирао у вазалној подређености Хабзбуршкој империји, на преласку у деведесете године ХХ века - када је империја мултинационалних корпорација под вођством САД у свој светски систем поступно интегрисала државе из распалог социјалистичког другог света - преузимају југословенска војска, Срби, српски, односно, хрватски језик и остали Југословени, означени као „несловенци“. У односу према тзв. несловенцима страхови су се мешали с комплексом веће вредности.

Логика ове идеолошке матрице је појединце у независној Словенији интерпелирала тако што су се дистанцирањем од тзв. јужњака, односно, „несловенаца“ поимали као Словенци, носиоци капиталистичке етике (марљивости, штедљивости, разумности) и (средњо) европске културе, једини чији је улаз у цивилизацију демократског Запада оправдан. ${ }^{5}$ Поменути су у словеначком лојалистичком имагинарију заузели структурни положај некадашњег господара, хабзбуршког монарха, док су „несловенци“ означавали Балкан. Прожети дискурсом међусобне суседске „оријентализације, која је каракте-

5 Дистанцирање од других Јужних Словена има дугу традицију. Словеначки културни национализам је у дугом XIX веку бранио идеју тзв. независности [словеначког] народа унутар Хабзбуршке монархије и упркос словенофилству одбијао (пансловенско, илирско или јуїословенарско) сливање словенских племена. Чак је и словеначка историјска прошлост у приказивању Јужних Словена осцилирала између савезничке наклоњености и ксенофобних предрасуда, на пример, према ускоцима (упореди: Hladnik 2005). 
ристична за целу Југославију, од њеног северозапада до југоистока (Bakić-Hayden [1995] га назива nestling orientalism, тј. оријентализам у оријентализму), многи су у Словенији замишљали Балкан као експлозивну мешавину наслеђа османске и византијске империје несамериве с поретком Запада.

Кључни разлог који је довео до избрисаних је етнонационалистичка концепција словеначке државе и других наследница СФРЈ (упореди: Conversi 2004; Kecmanović 2002), по којој су старо територијално начело пребивалишта и апстрактан појам човека-држављанина субординирани народом као имагинарним колективним субјектом с вишевековним историјским идентитетом. Легитимност независне Словеније, наиме, произилази „из воље словеначког народа“ (Ustava 2005: 9). За појединца се друштвена веза идеолошки утемељује на припадности етницитету као биолошки-културно одређеној заједници (заједнички род, језик, култура, колективно памћење и територија), док је његово цивилно држављанство секундарно. Етнонационализам као основа словеначког држављанства своје право лице показао је управо поводом избрисаних који су се због свог несловеначког рода сусрели са системском дискриминацијом у правним поступцима (упореди: Dedić 2003; Zorn 2003, 2007).

\section{Друштвене перцепције брисања и уметничка репрезентација}

Избрисани дуго нису били свесни да је брисање могуће, свако га је за себе доживео посредством шока доживљеног у контакту с управним органима и полицијом. Спасавајући се од невоље сами и помоћу ближњих, појединци су осцилирали између самооптуживања, наде да се ради о грешци и беспомоћног беса према држави (упореди: Lipovec Čebron i Zorn 2011). Mеђу словеначким бирократским службеницима преовладавало је убеђење да брисањем само извршавају закон, а етику и уставност самог чина нису доводили у питање. Ретки од њих су покушали помоћи избрисанима саветима, а други су их процесуирали с ненаклоношћу, с расистичким тоновима (упореди. Zorn 2003: 100-104). У јавности и медијима је о избрисанима, с ретким изузецима, готово десет година преовладавала тишина (Mekina 2007). Радило се о „културној анестезији“, како Ален Фелдман означава прећуткивање трауме мањина (Zorn 2003: 92-93).

Избрисани су тек 2002. године основали друштво и почели да одржавају редовне протесте, у домаћем и међународном простору. Пре тога су се за њих заузимали тек ретки новинари (у Млаgини још од 1994. године), интелектуалци и цивилне друштвене организације, нарочито Мировни институт. У реакцијама на референдум о избрисаним (2004. године) придружили су им се поједини писци (нпр. Борис А. Новак сонетом „Избрисани“). Након деценије ћутања 
топика избрисаних дошла је у само средиште јавног дискурса и то тек након пресуда Уставног суда које су 1999. и 2003. године утврдили противуставност поништавања права на поседовање сталног пребивалишта. Видљивости овог прекршаја допринели су поменути протести Друштва избрисаних и континуирана подршка домаћег и међународног леволибералног цивилног друштва. Социолози су анализирали правне, социјалне и политичке аспекте брисања (Dedić, Jalušić и др. 2003). Објављене су књиге о двема животним причама избрисаних с коментарима које разбијају непријатељске стереотипе (Lipovec Čebron i Zorn 2011).

Полемике о избрисаним су се распламтеле током прихватања закона који је по одлуци Уставног суда требало да исправи последице брисања. Националистичке политичке снаге порицале су противправност овог административног чина и спречавале исправљање грешке. Године 2004. изнудиле су референдум на којем је скоро 95 одсто гласача, од 31,45 одсто грађана који су изашли на гласање, одбило тзв. технички закон о избрисаним. У медијима су преовладавале заводљиве информације о броју и карактеристикама популације избрисаних. Представљани су као они који пружају помоћ агресорској JНА, као потуљени непријатељи Словенаца или незахвални шпекуланти, који, најпре одбивши великодушно понуђено словеначко држављанство, прорачунато очекују надокнаду, и представљају опасност за благостање Словенаца. Чак и након недвосмислене пресуде Европског суда за људска права који је 26. јуна 2012. године у брисању препознала кршење Европске конвенције о људским правима и Словенији наметнула обавезу да исправи последице, и даље преовладавају порицање кривице и негативна слика о избрисаним. Ради се о синдрому утаје масовног укидања људских права и негирање кривице, који је карактеристичан за дискурс „организоване невиности“ (Jalušič 2007) и „културе ћутања“ (Dimitrijević 2006: 378-381), не само у словеначком случају биополитичког насиља које је административно-полицијске врсте, већ и у случају ратних злочина у другим републикама бивше Југославије.

Романи којима ћемо се у наставку бавити заснивају се на друштвеној перцепцији избрисаних и приступају томе на естетски начин. Занимљиво је да су словеначки писци веома ажурно писали о ратовима на Балкану, док избрисани представљају ретку тему. Тема избрисаних словеначког аутора или читаоца не поставља у улогу неког ко од споља суди, као кад је реч о теми рата на Балкану, него у улогу сукривца. Дискурс организоване невиности се у овом случају ослања на убеђење о бенигности национализма тзв. малог народа и о демократској цивилизованости Словеније, којој је насиље, које се приписује Балкану, страно. За уздржаност у писању о избрисанима сноси одговорност и амбивалентан положај писца као друштвеног критичара који је истовремено и национални идеолог. Словеначка 
књижевност је била историјски носилац културног национализма, а књижевници су још од осамдесетих година XX века били идеолози и протагонисти независности (на пример, тзв. устав писаца из 1988. године). С друге стране, књижевници су традиционално наступали као критичка интелигенција, дистанцирана од владајуће идеологије. Међутим, критиком државе која је својим национализмом избрисане створила и скривала, писци би ризиковали излазак из традиционалног народотворног савеза књижевности, при чему нису могли знати да ли ће их читалаштво, навикнуто на културу ћутања и политику негирања, уопште прихватити.

Тема избрисаних почела је да се појављује у позоришту и књижевности након референдума, када је преплавила медије. Године 2005. доживела је - поред Новакове лирске проблематизације егзистенцијалног искуства искључености, отуђености и „унутрашње емиграције“ (Izbrisani) - и своје прво (аматерско) позоришно извођење које карикира добијање словенског држављанства. ${ }^{6}$ Године 2008. Горан Војновић је у свом успешном првенцу Južnjaci marš! [Čefuri raus!] први, иако маргинално, представио лик избрисаног становника мултикултурног насеља; три романа која тему избрисаних постављају у средиште излазе тек након пресуде Европског суда за људска права 2012. године. Пресуда је вероватно створила легитимацијску подлогу за списатељско противљење домаћој политици порицања. Сва три романа која ћемо обрађивати започињу процес суочавања с трауматичном сукривицом Словенаца за избрисане, укључујући и уметничке праксе мејнстрим медија. С колективном кривицом се 2013. године представом 25.671 ухватио укоштац и режисер Оливер Фрљић, enfant terrible постјугословенског политичког позоришта (упореди. Juvan 2014). Фрљићева постдрамска представа у Прешерновом позоришту Крањ проблематизује политике репрезентације избрисаних у јавном дискурсу и однос тзв. обичних Словенаца према избрисанима. Конкретна прича о комшијском искључивању и искоришћавању избрисане емигрантске породице илуструје пре свега говор и деловање етнонационализма унутар свакодневног живота ${ }^{7}$ К Као што је код Фрљића често случај, болно откривање националистичког зла било је чак и у крањској представи уоквирено оштром политичком саморефлексијом позоришне институције и

6 Комедију Izbrisani, мешавину stand-up комедије и хумора Той листие наgреалистй у у Крању су извели аматерски глумци Boom teatra пореклом из тзв. несловеначких породица.

7 Након што су избрисани у прологу поново уписани у регистар (њихова имена уписивала су се на полеђини сцене која евоцира Триглав, словеначки симбол), глумци представљају егземпларну причу о породици избрисаних коју комшије исељавају из домарског стана како би новцем добијеним од продаје платили реновирање зграде. Централну причу о патњи породице и самоубиству сина прекидају домобранске песме и цитати говора политичара и анонимних коментатора на интернет порталима који су усмерени против мањина. 
праћено моралним провокацијама учесника позоришног догађаја (на пример, свађа глумаца о референдуму о избрисаним, суочавање публике са правом породицом чију је причу на безбедан начин доживљавала посредством позоришне мимезе).

У поређењу с радикализмом Фрљићевог постдрамског позоришта, које све време пробија естетску дистанцу, три романа који тематизују искуство избрисаних и рефлектују однос већинског народа према њима процес друштвеног прерађивања трауме описују на начин који у књижевним приповестима преовладава јо од XVIII века надаље - преко миметичке репрезентације и естетског дискурса.

\section{Хронотоп мултикултурног насеља, егземпларност и биополитика}

Андреј Е. Скубиц је романом Фужински блуз (2001) у словеначку књижевност увео хронотоп приградског насеља. Важећи књижевни словеначки разбио је у социолекте, с додатком српскохрватског и словеначко-српскохрватских хибрида. Крај етнички гледано словеначких протагониста увео је несловеначке јунаке с њиховим животним и говорним стиловима. Скубичев хронотоп се односи на љубљанске Фужине, једно од стамбених насеља изграђено у седамдесетим и раним осамдесетим годинама XX века. У њу су се у периоду економске коњуктуре насељавали досељеници из мање развијених југословенских република. Хронотоп мултикултурног гета, уклопљеног у престоницу нове националне државе, одједном постаје мнемотоп (Asman 2011: 59) и хетеротопија (Fuko 2005); као умањени снимак југословенског простора у свом вишејезичком театру идентитета приказује разлику између савремености и ближе прошлости. У њему се праксе савремене урбане сегрегације суочавају с колективним памћењем југословенског идеологема братства и јединства и егалитарног стандарда социјализма.

На трагу хетероглосије Скубичевог хронотопа насеља, Горан Војновић се својим бестселером Јужнаци мари! (С̌efuri raus! 2008) усмерио на анатомију односа између младих и њихових досељеничких породица. Цело насеље трпи због незапослености, алкохолизма, дроге, (породичног) насиља и деликвенције, а од споља на њега утичу органи и медији словеначке државе као и драматичне промене у матичним државама досељеника. У галерију ликова који су због балканско-јужњачких призвука свог животног стила печатирани као чефури, ${ }^{8}$ Војновић уводи и једног избрисаног, али му додељује споредну улогу. ${ }^{9}$ У романима који су се у периоду од 2014. до 2015.

8 Наслов Војновићеве књиге у оригиналу гласи С̌efuri raus!; чефøp је, иначе, погрдна реч за досељенике из јужних република бивше Југославије. (Прим. иррев.)

9 Реч је о лику досељеника из Кикинде, који је са Словенком засновао породицу. На- 
године бавили проблемом избрисаних (Izbrisana Mihe Macinija, Kakorkoli (Kakogod) Polone Glavan i Kraj. Ponovo Dina Bauka, хронотоп мултикултурног насеља је оно што социјално одређује деловање, говорну садржину и поглед лика, али је хетероглосија хронотопа у стилистичко-наративном смислу речи важна само код Главанове.

У романима о избрисаним међу несловеначким ликовима симптоматично наступају и странци који су инстанца спољашњег посматрача словеначких друштвених прилика. Два лика долазе из САД и - невезано за карактерне особине - својим професијама маркирају идеолошко-економску анексију периферије која се суочава с ратовима и транзицијом и прилично заостаје за развијеном демократијом Запада. Денисова девојка Мери (Bauk) послата је у Словенију као мормонска мисионарка, а Залин партнер Марк (Macini) као кризни менаџер; оба лика недемократска одступања периферије процењују у светлу демократских стандарда центра. Све троје странаца-партнера ${ }^{10}$ су, дакле, карактеристична појава глобализације, која је у светски систем укључила словеначку државу, слободним током капитала, робе и људи пробудила транснационалност љубавних веза, а у словеначку књижевност унела глобални енглески.

Сва три романескна приступа теми избрисаних заснивају се на егземпларности, карактеристичној за миметичност књижевног дискурса (упореди: Johansen 2002: 415-432; Јуван 2011: 54-55). Буђењем емпатије посредством индивидуализоване приче која демантује стереотипе, они покушавају - преко ограниченог домета

кон брисања, будући да - за разлику од своје деце - није могао да добије словеначко држављанство, он се одаје пићу. - Кад је наша анализа три романа о избрисанима била већ завршена, Војновић је 2016. године издао аутобиографски обојен роман Smokva, у којем на позадини словеначко-југословенске историје од краја Другог светског рата до наших дана преплеће разне временске нивое прича о проблемима етнички мешаних и прекинутих брачних односа приповедача Јадрана, његових родитеља и њихових родитеља. У те догађаје, повезане с хронотопом мултикултурног насеља и препредене с језички хибридним дијалозима књижевних ликова, Војновић је поново унео тему избрисаних, али јој је дао већу тежину, будући да губљење права на стално пребивалиште трауматично обележава распалу породицу и својим поступним откривањем ствара приповедачку напетост. Канцеларијски службених Сафет Диздар 1992. године на необјашњив начин нестаје из дома у љубљанским Фужинама, где оставља сина Јадрана, тада тинејџера, и своју жену Весну, Словенку. Нестанак се појашњава поступно: Сафет је био прогнан из Словеније кад је, доживевши брисање (словеначко држављанство није желео добити ни уз помоћ пријатеља, високог чиновника Министарства за унутрашње послове, а губљење права на пребивалиште није очекивао) и на полицијској станици дао одушка свом бесу због уништених докумената и сепаратистичке државе која му је проглашавање независности уништила домовину. Из пркоса (тзв. инайа) након прогона, он одлучује да остане у земљи својих родитеља, у Босни, где управо почиње рат. Тамо се не осећа као код куће, већ поново пати због расцепљене припадности (сећања на Словенију, парадоксално, оживљава, на пример, читањем умрлица у новинама). Сафет, сналажљив, духовит и распуштен словеначки Босанеи, након брисања се у изгнанству претвара у резигнираног, озбиљног и повученог босанског Словенца. Брисање му је узело живот много пре него што ће то учинити смрт.

10 Аља се у роману Полоне Главан заљубљује у Ирца. 
који поседује књижевни говор - да скрену пажњу јавности на општу друштвену појаву (на избрисане) и да на фиктивном примеру конкретизују њене погубне последице. Приповест се, наиме, фокусира на појединца који метонимијски заступа масу коју дехуманизује доминантни дискурс. И Мацинијев роман Избрисана покушава преко егземпларне приче да пробуди у естетском дискурсу емпатију према популацији избрисаних. Протагонисткиња Зала се стога приближава уобичајеним представама о просечној словеначкој тридесетогодишњакињи, иако је начин на који је приказана оптерећен стереотипима о избрисанима (тзв. балкански темперамент, оптерећеност етнички мешаном патријархалном породицом, отац официр).

Мацинијева приповест је у трећем лицу, фокализована је посредством Зале, време догађања је документаристички згуснуто (од 30. априла до 15. маја 1992). Приближно два месеца након чина брисања Зала доживљава раздвајање цикличног и линеарног времена. Циклично време је утиснуто у индивидуално и културно сећање на социјализам (на празничне дане око 27. априла и 1. маја), а истовремено је преплетено с природним циклусом: мај је врхунац пролећа, а Зала се порађа током пролећних празника. Међутим, Залино линеарно време се удаљава од дневне рутине: она открива да је остала без здравственог осигурања, уништавају јој документе, покушавају да јој одузму новорођенче, губи посао, затварају је у азилни дом и имају намеру да је протерају као илегалну странкињу. Мацинијева егземпларна веза народа, националне државе и рођења Залиног детета је симптоматична. Словеначки интелектуалци су идеју народа као егзистенцијалну датост („рођеност“ [„narođenjost“]) и нужан услов демократије културолошки утемељивали на биологистичкој етимологији, дакле, управо на појмовима рођења и рода. ${ }^{11}$ Залин конфликт с националном државом рођеном неких годину дана пре времена догађаја у роману, почиње управо њеним порођајем. У породилишту сазнаје да је као избрисана за на-родну државу на порођају такорећи већ мртва (као грађанка), а њена новорођена кћер се из-родила из словеначког поретка рода.

Мацинијев хијазам рођења и симболичке смрти укључујући позорницу поменуте смрти - породилиште, које је приказано као Гофманова (2009) „тотална институција“ - могуће је уз помоћ Фукоа (2005: 431-437), Агамбена (2006: 103-114) и Еспозита (2015: 48-66) читати као симптом биополитике, тј. државног регулисања живота по-

11 Реч „народ“ долази од прасловенског „^narodi”ti ’породити' [...]“ и „дакле њено прво значење је *'који се рађа, настаје““ (Snoj 2015). - Филозоф Тине Хрибар у Расйравама о словеначком националном ироіраму (Hribar 1987) одваја „народ“, који се утемељује на „рођењу“ и „роду“ (natio), од „нације“; ова последња значи „народ са сувереном политичком влашћу, тј. с властитом државом“, чему пак „народ“ треба да стреми по својој историјској суштини (3-4). - Ова идеја долази из културног национализма XIX века, а приближава се биополитичком нексусу рођење - pog - нароg, о којем говоре Агамбен (2006: 110-114) и Еспозито (2015: 228-229) у вези с фашизмом. 
пулације с аспекта економичног и рационализованог „управљаштва“ неолибералне парадигме. Рационалном машинеријом биополитичког управљаштва суверена словеначка власт латила се избрисаних (погледај: Breznik, Križan и др. 2013) и то на начин који Залин случај делимично приказује. Зала, која доживљава себе као Словенку, иако је ћерка српског официра, брисањем се трансформише у илегалну странкињу. Из аспекта биополитике њен прогон допринеће смањењу југословенске популације у држави словеначког народа, државни буџет ће бити растерећен социјалних и здравствених трошкова, а присилним усвајањем њене ћерке ојачаће се народно тело. Биополитика делује на Залу на позорници тоталних институција (породилиште, азилни дом, полицијски притвор), бироа и служби (МУП, Центар за социјални рад), као и државних медија (Телевизија Словеније). И завера помоћу које директорка породилишта преко својих веза покушава Зали да одузме новорођену кћер има биополитички подтекст: она убеђује Залу како би је навела да да̂ ћерку на усвајање, будући да ће детету бити боље у „uglednoj porodici“ (Macini 2015: 77). Позадина директоркине привидне бриге је фашистоидна; она сматра да се таквим усвајањима „gradi zdrava nacija“ (77). ${ }^{12}$ За директорку је у савременој националној држави одлучујуће порекло („оvo je zemlja rodbinskih veza, a ne prava!“, 78). Избрисани, како их слика словеначки роман, проистичу из дисфункционалних, етнички мешаних породица, страних имагинарију породице као основне ћелије народно хомогеног словеначког друштва.

Споредним ликом избрисаног, Залиним пријатељем Николом, Мацини додатно осветљава како делује биополитичко управљаштво. У супротности с грађанином коме правни поредак гарантује људска права, брисање поставља личност у зону стања изузетости, правно одлучене искључености из правног поретка (упореди: Zorn 2007: 28-29; Agamben 2006: 106-124). Стање изузетости дисциплинује голи живот избрисаних: као и Никола они су морали да воде рачуна да својим незаконитим делатностима неопходним да би преживели и радом на црно не привуку пажњу, иначе би могли бити прогнани.

\section{Жанр трилера као глобалистички pharmakon}

Критику биополитичке регулације популације која на темељу етнонационализма искључује и економски искоришћава избрисане у Мацинијевом роману блокирана је преузетим жанром црног трилера (the noir thriller). Према Хорслију теме црног трилера произлазе из „судбоносног односа протагонисте и друштва. Ликови пате због уништене могућности деловања [...] или изгубљене везе

12 Директоркино убеђење надахнула је биополитика франкизма, која је након грађанског рата присилно одузимала децу републиканским или сиромашним мајкама и давала их на усвајање имућним породицама наклоњеним фаланги и цркви. 
са заједницом (Horsley 2009: 11). Овај жанр протагонисте „суочава с пукотином у обичном поретку ствари“, те стога постају „опседнути, отуђени, рањиви, гоњени или параноични“; силе које их угрожавају су приказане као апсурдне случајности, а на друштвеној равни као „кривице, грешке, предрасуде или притисци“. То значи да су „силе које надзиру живот ликова засноване на преовлађујућим концепцијама друштвенополитичких детерминанти“, међу којима су и економска ускраћеност и искљученост из конформистичког, предрасудама оптерећеног друштва (Horsley 2009: 11).

Мацинијев роман поседује многе карактеристике црног трилера, ако не занемаримо преклапања с криминалним или шпијунским романом. У складу са сценаријем трилера појединка (Зала) налеће на индиције злослутне отуђености свог света, који се из присног претвара у непријатељски и недомаћи (unheimlich); она губи могућност надзирања догађаја. Као прикривен актант алијенације посредством наративне напетости и параноидне логике трилера открива се завереничка мрежа коју повезује нетолеранција према несловенцима. ${ }^{13}$ По обрасцу трилера Зали припада улога прогањане жртве коју губљење држављанства отуђује тако да се сама не може одупрети погубном низу апсурда који генерирају неправедно друштво и завереничка мрежа око директорке породилишта. За помоћ се обраћа Американцу Марку, свом бившем љубавнику и оцу њене ћерке. Као што је типично за жанр, Марк јој предлаже да помоћу новинара, интелектуалаца и креатора јавног мнења обезбеди подршку јавности, а мрежу која хоће да јој одузме дете медијски раскринка и у томе онемогући.

Упркос Залиним неуспелим покушајем продора у јавност ${ }^{14}$ преузета матрица трилера ипак опстаје. У помоћ мора да прискочи тзв. независан медиј, који наступа као универзални одбрамбени зид демократије. Тек након што Залин случај прикаже глобална телевизија $C N N$, словеначка јавност се буди услед страха од мишљења хегемона и лоше слике о Словенији у међународном простору. Зато се Зали додељује словеначко држављанство и враћа јој се дете. Мацини поступа доследно: не само да у словенизованом америчком жанру види одговарајуће оруђе за критику словеначког друштва и откривање истине о избрисанима, већ унутар преузетог жанра улогу помоћника додељује управо америчком бизнисмену и $C N N$-у. Мацинијев роман је, дакле, увозом жанра несвесно преузео и његов империјалистички пртљаг.

13 Злокобна мрежа, која може бити такође Залина параноидна фантазма, присваја легални друштвени поредак преко појединаца: тријажне сестре, директорке породилишта, социјалне раднице, полицајаца, медијског уредника и писца.

14 Наступ на јавној телевизији у име виших политичких интереса Зали најпре онемогућава конформистички уредник; подршку јој не пружа ни угледни писац, ни савест народа ни интелектуалац кога субвенционира држава. Када јој напокон пође за руком да наступи у ТВ емисији, не догађа се ништа што одступа од модела америчких филмова (то каже Зала сама). - Тиме Мацини наговештава зашто је брисање у словеначким медијима тако дуго било прећуткивано. 
C амбиваленцијом Платоновог означитеља pharmakon, који у вези с писањем на метафизичкој равни обрађује Дерида у La pharmacie de Platon (Derrida 1972), у дискурсу Мацинијевог романа, на равни политике писања, поклапа се амбиваленција трилера као епистемичког жанра. Мацини наиме у својом егземпларном наративу као лек за недемократску словеначку патологију користи писмо глобалног жанра. Писање трилера би лековито открило истину (о избрисаним), иако одједном делује као отров (неолибералне, глобалистичке) идеологије која је у светским размерама створила односе у којима је словеначка патологија уопште могла да настане.

\section{Литераризација погледа на избрисане}

Док се Мацинијев роман Избрисани фокусира на егземпларну индивидуу, Полона Галван (Kaкоїog) и Дино Баук (Крај. Поново) захватају дуже време догађања и наратив премештају у полифигуралност. Њих више интересују односи према избрисаним него прича о једном избрисаном. Главанова и Баук истичу саодговорност коју држављани Словеније имају поводом брисања, чиме се провоцира дискурс порицања. Међутим, док Мацини оптужује јавне службенике који изводе или злоупотребљавају брисање, Главанова и Баук, посвећују своју пажњу тзв. обичним људима. Такви су, на пример, Бауков бизнисмен Горан и културни бирократа Петер. Њих двоје пате од осећаја кривице јер се нису довољно потрудили за спас заједничког пријатеља Дениса, који је након брисања прогнан на балканска подручја захваћена ратом. Идеолошко-социолекталну диференцираност односа према избрисанима романи Главанове и Баука приказују посредством плуривокалне и плурифокалне приповедачке структуре у којој ликови заступају хабитусе различитих друштвених група.

Баукова приповест, укључујући ретроспективе, обухвата око две деценије. Вршњаци из комшилука међусобно се удаљавају не само због карактерних разлика већ и због нарастања друштвених разлика у периоду транзиције. У роману је присутан мотив конфликта између радника и капитала који је букнуо у тзв. дивљој приватизацији. Какоїog Полоне Главан има карактеристике друштвеног романа будући да преко љубавних прича две младе жене - време догађања је око девет месеци, колико траје трудноћа једне од њих - сецира савремено словеначко друштво под светском владавином неолиберализма. Списатељица слика друштвено пустошење током пропадања социјалне државе, али на другој страни осветљава и буђење солидарности, активизма, отпора против таквих друштвених односа.

Приповедачи у првом лицу романа Какоі̄og су Аља, студенткиња англистике, коју хуманитарни нерв води у борбу за права избрисаних, и Лили, трудна средњошколка из нижег средњег слоја, 
која се бива с скинхедом националистом, непријатељем избрисаних. Њихове контрастне приче су посредоване преко два различита социолекта, „култивисаног“ и „ексцесног“ (упореди: Skubic 2004).

Аљин култивисани студентски социолект поклапа се с њеном карактеризацијом, будући да је она носилац хуманистичких и леволибералних вредности, као што су самоовладавање, толерантност, прилагодљивост, отвореност за другојачност и несебична помоћ слабијима. Аља помаже основношколцу Сенаду из босанске породице да поправи школски успех тако што му држи часове. Будући да је потреса беда породице која живи у малом стану у етнички мешаном насељу, подршка коју пружа дечаку интензивира се у социјалну помоћ коју заједно с другарицама пружа његовој породици. Придруживањем левичарским активистима у љубљанском сквоту Рог она своју емоционалну филантропију подиже на заједничку политичку раван. Укључује се у борбу за права свих затираних заједница, међу њима и избрисаним. Полона Главан својом нарацијом понире у догађаје након 2000. године, кад су се избрисани као организована заједница и политички субјект почели јавно борити за своја права, при чему на њихову страну ступају невладине организације и активисти из Словеније и иностранства. ${ }^{15}$ На супротној страни налази се други приповедач романа, седамнаестогодишња Лили. Њен „ексцесни“ говор, који спада у „маргиналне градске социолекте“ (Skubic 2004), прожет је тинејџерским сленгом. Будући да Лили не подноси култивисано самонадзирање, њен говор је маркиран расистичким изразима за мигранте и означитељима нетолерантног дистанцирања од свих који не припадају њеној тинејџерској супкултури. Ако код Ање хуманитарни активизам прераста у подршку другачијима. У Лилиној причи њен спонтани расизам - који упија кроз социјализацију у окружењу породице и вршњака - под утицајем њеног дечка, који припада скинхедима, развија се у експлицитну идеологију и води у манифестацију којом бесне „словеначке патриоте“ желе да скрену пажњу на оно за шта су ускраћени и да растуре протесте у име избрисаних и других маргиналних заједница.

Списатељица није Лили приказала као негативан лик, напротив, она се уживљава у њен свет. Догађање романа ограничено је месецима Лилине трудноће. Чак и Марсово окретање скинхедима објашњава се као хабитус одређен његовим социјалним положајем. Марс долази из растурене породице и не може себи да приушти високошколско

15 Александер Тодоровић, који је новембра 2001. године штрајковао глађу, оснива Друштво избрисаних пребивалаца Словеније десет година након брисања (26. 2. 2002). Сваке године на дан брисања од 2003. године друштво приређује недељу избрисаних. У љубљанском сквоту АКЦ Метелкова 2003. године отворена је изложба о избрисаним и представљена монографија на ову тему. Априла 2006. у љубљани били су одржани противрасистички протести, новембра исте године Тодоровић је уз подршку словеначких, италијанских и француских невладиних организација организовао Караван избрисаних од Љубљане до Брисела (Pistotnik 2007: 212-217, 232-235). 
образовање. У прекарном друштвом препуштен је вољи надређених и профитабилности трговачког предузећа. Ова ускраћеност Марса баца у беспомоћан бес због којег губи посао. Из аспекта фројдовског објашњења фашистичке друштвене везе (Adorno 2013) произлази да се Марс од свог рањеног нарцизма под утицајем неонацистичких идеолога спасава помоћу механизама масовне психологије: неостварени идеал јаства пројектује на вођу неонациста своју либидиналну енергију инвестира у заједницу која за њега представља фантазму народног организма. Списатељица, на Марсовом примеру, показује како ускраћени радници - неопремљени за критичку анализу свог положаја - постају плен популистичких решења какво пропагира фашизам прилагођен неолибералном добу. ${ }^{16}$

\section{„Избрисани“ као модерна трагедија без катарзе}

Антички појам трагедије је већ Хегел прилагодио модерном времену, а Рејмонд Вилијамс и Тери Иглтон су њену каноничност повезали с осећајем за трагично унутар структура свакодневног живота и обичног језика. Лили и Марс, млади људи пореклом из нижег слоја, одговарају Хегеловој дефиницији колебљивих романтичних карактера који представљају прави темељ модерне трагедије и стоје „usred mnogobrojnih slučajnih prilika i uslova“17 (Hegel 1975: 627, 630). Стиче се утисак да су њих двоје субјекти који остварују „princip individualne slobode i samostalnosti“, што је по Хегеловом мишљењу нужан услов за „istinsko tragično delovanje“18 (611). Међутим, њихови поступци конфронтирају их с њиховим „subjektivni[m] cilj[em]“ и „ličnom straš[ću]“ (612), будући да су детерминисани контрадикцијама касног XX века. Ови историјски процеси су структурно аналогни „umnost[i] sudbine ${ }^{\text {“19 }}$ у античкој трагедији (620), односно, „božansko[m] koje ulazi u svet, u individualno delanje“ трагичких јунака (601), али с одлучујућом разликом: у историји уместо божанског Провиђења или апсолутног духа влада случајност економско-политичких промена. На Лили и Марса, модерне трагичке карактере, историјски процеси делују преко контингентних догађаја, који за

16 Фашизам, какав се уводи под окриљем „непосредне власти наднационалних корпорација над денационализованим, социјално разбијеним и политички ликвидираним људством“ (Mastnak 2015: 144, 159), усмерава немоћан бес искоришћених у препознатљиве и слабије мете - припаднике маргиналних друштвених група. Фашистичка пропаганда постнационалистичког доба држи се рецепата своје историјске претходнице, будући као „агент моћних економских и политичких интереса“ (Adorno 2013: 54; погледај и: Dolar 1982: 11-26) приказује рањиве популације као мање вредне друге који угрожавају радна места народно хомогених малих људи, њихов стандард, егалитаристичнки морал и ужитак националне идентификације.

17 Превод је унеколико коригован. (Прим. иррев.)

18 Превод је унеколико коригован. (Прим. ӣрев.)

19 Превод је унеколико коригован. (Прим. иррев.) 
њих почињу непланираном трудноћом, а завршавају се нехотичним убиством. Њихова прича одговара двема Хегеловим одређењима модерног „tragičnog ishoda“: по првом „se individue sukobljavaju s nekom realno postojećom silom [...] želeći da uprkos njoj ostvare svoje ciljeve“ (634-635), а по другој је трагички исход „posledica nesrećnih prilika i spoljašnjih slučajnosti koje su tako isto mogle [...] da se završe srećno“(635).

Марсова неиживљена расистичка агресивност одређује његов „patos“ и „jednostranost“ у његовом деловању и говору; неизоставно га доводи до „subjektivne patnje“, слома и трагичке кривице (упореди: Hegel 1975: 602). Стопљен с колективним духом фашистичке масе Марс се игром случаја претвара у убицу. У метежу борбе левичарских и десничарских демонстраната он смртно рањава Нихада (оца Аљиног ученика Сенада, који је инвалид), који се случајно затекао тамо. Због тог нехотичног злочина пропада и Марсова и Лилина интимна, премда расистички обојена жеља да ће са својим новорођеним дететом створити нов породичан живот у чисто словеначком крају града.

Крај Лилине приче разбија представу о „tragičnom izmirenju“ као „ukidanju suprotnosti“ из којих произлази трагедија; Хегелово трагично измирење по цену жртве протагониста измирује трагични конфликт између два једнако оправдана, а једнострана морална циља (Hegel 1975: 613-624). Уместо Хегелове реконструкције порушене друштвено-метафизичке хармоније, која би требало да у публици старе и модерне трагедије пробуди катарзу и осмисли саосећање с патњом трагичног јунака, у роману Полоне Главан јавља се апсурд и алијенација: Лили на крају романа, насупрот стереотипној слици породиље, не жели ни да погледа своје дете, ћерку оца који ће остати обележен тиме што је убица. У истом таквом апсурдном расплету трагичног запета налази се и Аља. И Аља осећа апсурд и кривицу јер је на демонстрације за подршку избрисанима лакомислено позвала и тешко болесног Нихада и тако нехотице допринела његовој смрти, иако је њему и њему сличнима својим идеалистичким активизмом - који стоји насупрот „jednostranosti“ Лили и Марса - одувек желела да помогне. У трагички расцеп између неразрешиве контрадикције историје (као судбине) и субјективне спознаје, морала и циља појединца уписује се, дакле, моменат случајности карактеристичан за структуру савременог света. Уместо катарзе која произлази из трагичног измирења, читалац романа Какоїog на крају долази до непомирљивог хијатуса који стоји између конфликтних светова. ${ }^{20}$

20 Придев, односно, везник како год „изражава случајност начина“ (Речник словеначког књижевног језика), индиферентност поводом различитих саопостојећих могућности. 


\section{Траума, кривица и имагинарно зацељење}

На другачији начин но код Полоне Главан, у првом делу Бауковог романа социолектима је обојен само говор носећих приповедачких ликова, док се приповедач у трећем лицу држи књижевног језика; у последњем делу романа ови фокализатори преузимају улогу приповедача у првом лицу, али само у епистоларној форми. Баукови протагонисти су пријатељи из приградског насеља из времена социјализма; крајем осамдесетих година они оснивају рок бенд који се распада у постјугословенском периоду. Денис је књижевно надарен младић из досељеничког брака и брисање га одводи у рат у Босни; Горан, који је већ као младић оријентисан на зараду постаје аморалан транзициони бизнисмен; Петер, студент хуманистике који је обећавао, након пропалог брака постаје огорчен културни бирократа. Четврти носећи лик је америчка мисионарка Мери, Денисова девојка. Денис, попут Мацинијеве Зале, долази из дисфункционалне, етнички мешане породице и у спору је с патријархалним оцем, несловеначким официром ЈНА. Ипак, Дениса, који код Баука заступа масу избрисаних, сналази не само редукција на голи живот него и губитак самог живота. У ланцу апсурдних случајности које произлазе из изузимања из регистра грађана са сталним пребивалиштем, Денис је ухапшен као илегални странац, прогнан у Хрватску и тамо присилно мобилисан, а потом и убијен као војник једног од зараћених „племена“ у распарчаној Босни. ${ }^{21}$

У наративима Главанове и Баука одвојени светови главних ликова се на крају укрштају. Обе приповедачице романа Какоїоg, које живе паралелне животе недалеко једна од друге, у закључним сценама романа срећу се у метежу напада фашистичке деснице на левичарске протесте. Аља и Лили, свака на својој страни масе и свака на свом социолекту, дају глас хаотичној перцепцији истих догађаја (демонстрација и Марсовог смртоносног ударца Нихада) у којима су се нашли, а да се притом не познају. Чак и приче раздвојених Баукових протагониста се поново пресецају. Пријатеље удаљавају како последице брисања тако и продубљивање друштвених разлика, а босански војни метеж, у којем је Денис убијен, непоправљиво их раздваја. Међутим, њихове жеље, сећања и осећаји кривице их поново зближавају, иако у имагинарном простору.

Баукови млади пријатељи се срећу у некаквом склоништу у библиотеци или у близини библиотеке. Хетеротопију библиотеке, простора у којем су похрањена књижевна упризорења других простора, писац представља у фантастичној перспективи тако да читалац у складу с дефиницијом овог жанра осцилира између природе и

21 Светлана Васовић (2007) наводи да постоји око десет случајева избрисаних који су након прогона из Словеније убијени у ратовима на Балкану (упореди: Zorn 2003: 115-123). 
натприродног објашњења описаних догађаја (Todorov 2010). Денис, прилагођен наметнутој улози војника, у једном босанском граду доспева до „кабриолет библиотеке“, обичне градске библиотеке која је отуђена на ониричан начин. Кров је уништен и у њој се некадашњи библиотекари приказују као духови. Рушевине су попут фрагмента историје саме по себи алегоричне, библиотека без крова евоцира како националистичку ратну деструкцију заједничког хуманистичког наслеђа некадашње Југославије тако и жилавост књижевности као духовне силе која својом виртуалном потенцијалношћу наговештава могућност новог почетка. У причама које говоре Мери и Денис, библиотека има надреалне карактеристике: тајновита библиотекарка Дениса води у простор у којем су сачуване постјугословенске књиге које ће бити написане тек по његовој смрти (поменути су Александар Хемон, Давид Албахари, Игор Штикс, Борис Дежуловић и Миљенко Јерговић), док се Мери у иностранству затиче између тајне четири полице назване Bibliotheca balcanica.

У поређењу с романима Мацинија и Главанове, код Баука - не само у призорима библиотека - очигледнија је носталгија за заједничким југословенским културним простором. Помоћу референци на познате песме и музичаре приповедач евоцира омиљене рок и панк бендове. Помиње познате хрватске, српске и босанске писце; неки су постали етаблирани тек последњих година, непосредно пре распада социјалистичке федерације, док су други нешто касније постали иконе „југосфере“ (Djokić 2013: 74), такође захваљујући њиховој тематизацији рата на Балкану и критичког става према национализмима. Поменути мотиви су иначе мнемотехника буђења рок и књижевног наслеђа Југославије, међутим, Бауков роман не запада у југоносталгију (упореди: Baskar 2007; Velikonja 2013), која је настала као масовна спонтана реакција на тежње владајуће политике у државама наследницама да потисну или маргинализују сећања на бившу државу. Књижевност, која је, као институција народа на просторима бивше Југославије, посредством националистичких писаца и интелектуалаца ширењем народних митова и непријатељских хетерослика седамдесетих и осамдесетих година XX века довела до насилног краја Југославије, код Баука се трансформише у утопијски простор културног памћења и могућности почетка другачијег суживота. Међутим, ову југоносталгичну утопију и имагинарно зацељивање трауме крај романа доводи до уништења.

Епистоларна нарација у последњем одељку романа, наиме, све надреалне просторе (поред библиотека, ту је и ковчег у којем се менаџер Горан скрива од побуне радника) и ониричко здруживање декодира у реалистичком кључу. Ови простори се показују као обрада места догађаја које књижевни ликови замишљају у својим сновима, а помоћу којих беже од стварности која их одваја. Мери, на пример, у писму мајци пише како је у једној западноевропској библиотеци 
упознала библиотекарку из срушене босанске библиотеке, која јој је рекла да је у рушевинама библиотеке видела једног војника (опис одговара Денису), пре него што га је упуцао његов надређени. Непосредно пре смрти Денис пише својим пријатељима о томе како је као војник замишљао простор у којем се поново сви срећу. Његов опис имагинарног склоништа поклапа се с карактеристикама надреалног простора у првом делу романа.

Баукови надреални простори су, дакле, књижевни троп. Фантастично-онирички свет у књижевном тексту фигуративно заступа психичку стварност фантазија, халуцинација, носталгије и жеље за новим почетком. Фантазмагоријском пројекцијом ових простора, које нарација повезује, протагонисти Бауковог романа беже од осећаја кривице и немоћи пред апсурдним током судбинских случајности преко којих на њих делује историја брисања. Међутим, упркос овим романима о избрисанима, траума и даље остаје необрађена. Књижевност се помоћу њих касно придружила силама супротним доминантном дискурсу „организоване невиности“, па ипак, прерађену трауматичну сукривицу за брисање тзв. обичних људи у приповестима она не доводи до очишћења, катарзе.

\section{ИЗВОРИ}

Bauk, Dino. Kraj. Ponovo. Prevela Dragana Bojanić Tijardović. Beograd: Rende, 2019.

Frljić, Oliver, režiser. 25.671: autorski projekt. Kranj: Prešernovo gledališče, 2013. Video-snimak.

Glavan, Polona. Kakorkoli. Ljubljana: Beletrina, 2014.

Macini, Miha. Izbrisana. Prevela Dragana Bojanić Tijardović. Beograd: Orion Art, 2015.

Novak, Boris A. „Izbrisani“. Obredi slovesa. Ljubljana: Študentska založba, 2005. 44.

Skubic, Andrej E. Fužinski bluz. Preveo Roman Vehovec. Novi Sad: Vega media, 2008.

Vojnović, Goran. Južnjaci marš! Prevela Ana Ristović. Beograd: Rende, 2009.

Vojnović, Goran. Smokva. Prevela Dragana Bojanić Tijardović. Beograd: Rende, 2017.

\section{ЛИТЕРАТУРА}

Adorno, Theodor W. „Freudovska teorija in struktura fašistične propagande". Preveo Rado Riha. Problemi 51. 1-2 (2013): 31-57.

Agamben, Giorgio. Homo sacer: suverena moć i goli život. Preveo Mario Kopić. Zagreb: Multimedijalni institut, 2006. 
Asman, Jan. Kultura pamćenja: pismo, sećanje i politički identitet u ranim visokim kulturama. Preveo Nikola B. Cvetković. Beograd: Prosveta, 2011.

Bakić-Hayden. „Nesting Orientalisms: The Case of Former Yugoslavia“. Slavic Review 54. 4 (1995): 917-931.

Baskar, Bojan. „Austronostalgia and Yugonostalgia in the Western Balkans“ Europe and Its Other: Notes on the Balkans. Ur. Božidar Jezernik i dr. Ljubljana: FF, 2007. 45-62.

Breznik, Maja, Kržan, Marko i Močnik, Rastko. „Upravljavske tehnike ob izbrisu“. Annales: Ser. hist. sociol. 23.1 (2013): 145-154.

Breznik, Maja, Močnik, Rastko. „Erasing Residence Rights in Slovenia“. Refugee Watch 38 (2011): 77-103.

Conversi, Daniele (ur.). Ethnonationalism in the Contemporary World: Walker Connorand the Study of Nationalism. London; New York: Routledge, 2004.

Dedić, Jasminka. „Diskriminacija v postopkih pridobivanja slovenskega državljanstva“. Izbrisani: organizirana nedolžnost in politike izključevanja. Ur. Jasminka Dedić i dr. Ljubljana: Mirovni inštitut, 2003. 23-84.

Dedić, Jasminka, Vlasta Jalušič i Jelka Zorn. Izbrisani: organizirana nedolžnost in politike izključevanja. Ljubljana: Mirovni inštitut, 2003.

Derrida, Jacques. „La Pharmacie de Platon“. La Dissémination . Pariz: Ed. du Seuil, 1972. 69-198.

Dimitrijević, Nenad. „Moral Justification of (the Idea of) a Truth Commission". Journal of Conflict Resolution 50. 3 (2006): 368-382.

Djokić, Dejan. „The Past as Future: Post-Yugoslav Space in the Early Twenty-Frist Century“. After Yugoslavia. Ur. Radmila Gorup. Stanford: Stanford UP, 2013. 55-74.

Dolar, Mladen. Struktura fašističnega gospostva. Ljubljana: DDU Univerzum, 1982.

Dolenc, Danilo. „Priseljevanje v Slovenijo z območja nekdanje Jugoslavije po drugi svetovni vojni“. Priseljenci. Ur. Miran Komac. Ljubljana: Inštitut za narodnostna vprašanja, 2007. 69-102.

Eagleton, Terry. Sweet Violence: The Idea of the Tragic. Oxford: Blackwell, 2003.

Esposito, Roberto. Bios: biopolitika in filozofija. Prevela Mojca Mihelič i Boštjan Nedoh. Ljubljana: Založba ZRC, ZRC SAZU, 2015.

Fuko, Mišel. „Druga mesta“. 1926-1984-2004 Hrestomatija. Ur. Pavle Milenković i Dušan Marinković. Preveo Pavle Milenković. Novi Sad: Vojvođanska sociološka asocijacija, 2005. 29-36.

Фуко, Мишел. „Рађање биополитике: предавања на Колеж де Франсу 1978-1979“. Превела Бојана Новаковић [и др.] Нови Сад: Светови, 2005.

Frojd, Sigmund. Nelagodnost u kulturi. Preveo Đorđe Bogičević. Beograd: Rad, 1988.

Goffman, Erving. „Characteristic of Total Institutions“. Asylums: Essays on the Social Situation of Mental Patients and Other Inmates. New Brunswick, London: Aldine Transaction, 2009. 1-124. 
Gregorčič, Marta. „Fantomska neodgovornost ali fašizem v preoblekah“. Časopis za kritiko znanosti 36.228 (2007): 81-97.

Hegel, Georg Vilhem Fridrih. Estetika III. Preveo Nikola Popović. Beograd: Beogradski izdavačko-grafički zavod, 1975.

Hladnik, Miran. „Slovani v slovenski zgodovinski povesti“. Podoba tujega $v$ slovenski književnosti. Ur. Tone Smolej. Ljubljana: Filozofska fakulteta, Oddelek za primerjalno književnost in literarno teorijo, 2005. 53-66.

Horsley, Lee. The Noir Thriller. Basingstoke: Palgrave Macmillan, 2009.

Hribar, Tine. „Slovenska državnost“. Nova revija 6.57 (1987): 3-56.

Jalušič, Vlasta. „Organizirana nedolžnost“. Izbrisani: organizirana nedolžnost in politike izključevanja. Ur. Jasminka Dedić i dr. Ljubljana: Mirovni inštitut, 2003. 7-22.

Jalušič, Vlasta. „Organizirana nedolžnost in izključevanje: nacionalne države in državljanstvo po vojni in kolektivnih zločinih". Časopis za kritiko znanosti 36. 228 (2007): 101-121.

Johansen, Jørgen Dines. Literary Discourse: A Semiotic-Pragmati Approach to Literature. Toronto: University of Toronto Press, 2002.

Juvan, Marko. „Od političnega gledališča v jugoslovanskem socializmu do političnega performansa v globalnem kapitalizmu: primer Slovenskega mladinskega gledališča“. Slavistična revija 62. 4 (2014): 545-558.

Јуван, Марко. „Наука о књижевности у реконструкцији: увод у савремене студије књижевности“. Превела Миљенка Витезовић. Београд: Службени гласник, 2011.

Kecmanović, Dušan. Ethnic Times: Exploring Ethnonationalism in the Former Yugoslavia. Westport, Conn.: Praeger, 2002.

Lipovec Čebron, Uršula; Zorn, Jelka (ur.) Zgodbe izbrisanih prebivalcev. Ljubljana: Sanje, 2011.

Mastnak, Tomaž. Liberalizem, fašizem, neoliberalizem. Ljubljana: Založba ${ }^{*} \mathrm{cf} ., 2015$.

Mekina, Igor. „Izbris izbrisa“. Časopis za kritiko znanosti 36. 228 (2007): 157-170.

Medvešek, Mojca. „Razmišljanja o pojavih nestrpnosti in etnične distance v slovenski družbi“. Priseljenci. Ur. Miran Komac. Ljubljana: Inštitut za narodnostna vprašanja, 2007. 187-217.

Mežnarić, Silva. „Bosanci“: a kuda idu Slovenci nedeljom? Prevela Seta Knop. Ljubljana: Republiška konferenca ZSMS: Univerzitetna konferenca ZSMS, 1986.

Pistotnik, Sara. „Kronologija izbrisa 1990-2007“. Časopis za kritiko znanosti 36. 228 (2007): 204-237.

Skubic, Andrej E. „Sociolekti od izraza do pomena: kultiviranost, obrobje in eksces“. Aktualizacija jezikovnozvrstne teorije na Slovenskem. Ur. Erika Kržišnik. Ljubljana: Center za slovenščino kot drugi/tuji jezik pri Oddelku za slovenistiko Filozofske fakultete, 2004. 297-320.

Snoj, Marko. Slovenski etimološki slovar. Tretja, elektronska izdaja. Ljubljana: Založba ZRC, ZRC SAZU, 2015. https://fran.si/193/marko-snoj-slovenski-etimoloski-slovar 20. 6. 2019. 
Todorov, Cvetan. „Određenje fantastičnog“. Uvod u fantastičnu književnost. Prevela Aleksandra Mančić. Beograd: Službeni glasnik, 2010. 26-41.

Vasović, Svetlana. „Izgon v smrt“. Časopis za kritiko znanosti 36.228 (2007): 171-176.

Velikonja, Mitja. ,'Something Has Survived...': Ambivalence in the Discourse About Socialist Yugoslavia in Present-Day Slovenia“. After Yugoslavia. Ur. Radmila Gorup. Stanford: Stanford UP, 2013. 115-122.

Zdravković, Lana. „Kaj je izbris? Kdo so izbrisani? Zakaj se to tiče vseh nas?“

Zorn, Jelka. „'Mi, etno-državljani etno-demokracije': nastajanje slovenskega državljanstva." Časopis za kritiko znanosti 36.228 (2007): 17-33.

Zorn, Jelka. „Politike izključevanja v postopkih pridobivanja slovenskega $\mathrm{dr}$ žavljanstva“. Izbrisani: organizirana nedolžnost in politike izključevanja. Ur. Jasminka Dedić i dr. Ljubljana: Mirovni inštitut, 2003. 85-139.

Ustava Republike Slovenije. Ljubljana: Mladinska knjiga, 2005.

Williams, Raymond. Modern Tragedy. London: Chattoand Windus, 1966.

Marko Juvan

The "Erased" between the Politics of Denial and the Exemplarity

of the Contemporary Slovenian Novel

Summary

Soon after Slovenia's proclamation of independence in 1991, the Slovenian authorities removed about 25,000 people (designated the "erased") from the registry of permanent residents. They thus disenfranchised and turned this group into illegal aliens reduced to "bare existence" (Agamben). The removal resulted from the ethno-nationalist concept of the Slovenian state and became an instrument of its biopolitical governmentality. The powers that be sought to minimize the size of the ethnically non-Slovenian population, suspecting it of disloyalty and stamping it with the Balkanist stereotypes typical of "nesting Orientalism" (Bakić-Hayden). The distancing from the "Southerners" allowed the Slovenians to perceive themselves as holders of a pristine work ethic and the (central) European democratic culture, suitable for entry into the global empire of late capitalism. After a decade of silence, the topic of the "erased" flooded the media as a response to verdicts by the Slovenian Constitutional Court and the European Court of Human Rights, which demanded that the state correct the injustice done to them. The political debate on their removal from the registry (the "erasure") reached its peak during the 2004 referendum on this problem. Moreover, those that were "erased" organized themselves to fight for their rights in 2002 and their campaigns were supported by the international leftist activists and civil society. However, a discourse of "organized innocence" (Jalušič) prevails in relation to this group, similar to the denial of war crimes in the post-Yugoslav countries.

Literature started to resist the politics of denial rather late and within the limits of the mimetic aesthetic representation. Although they addressed the wars in the Balkans in a timely manner, the Slovenian writers risk breaking their traditional 
ideological bond with the nation if they criticize the nationalist violence in their own country and compel their readers to play the role of accomplices instead of that of external arbitrators. Published in 2014 and 2015, three novels about the "erased" touched on the social processing of the trauma. With their exemplary narratives, they sought to evoke the sympathy for the group: they metonymically replace the dehumanized crowd managed by biopolitics with the humanized individual victims. In Miha Mazzini's The Erased, however, the appropriation of the global genre of the noir thriller ideologically constricts the critique of biopolitics of the "erasure." Polona Glavan, in her social novel Anyway represents the sociolectal differentiation of the perspectives on the group through the pattern of the modern tragedy, replacing conciliatory closure with a troubled scene of historical contingency. Dino Bauk's novel The End. Again depicts how ordinary people (friends from a multicultural neighborhood) deal with their sense of guilt for not helping the "erased". Using the elements of the fantastic genre, the author evokes how helpless literature is in healing the trauma of the removal, notwithstanding its mnemonic capability and virtuality.

Keywords: biopolitcs, ethnonationalism, trauma, denial of guilt, Slovenian novel, exemplarity

Превео са словеначког Иван Антић 